\title{
Pengaruh substitusi gula pasir dengan ekstrak jagung manis (Zea mays $l$ sacchara) terhadap sifat organoleptik es krim
}

\author{
C. Lamere, S.E. Siswosubroto*, R. Hadju, M. Tamasoleng \\ Fakultas Peternakan Universitas Sam Ratulangi Manado 95115 \\ *Korepondensi (corresponding author): edmund1403@gmail.com
}

\begin{abstract}
ABSTRAK
Penelitian ini bertujuan untuk mengetahui tingkat kesukaan panelis terhadap es krim dengan substitusi gula pasir dengan ekstrak jagung manis. Penelitian ini menggunakan rancangan acak lengkap (RAL) dengan 5 perlakuan sebagai berikut $\mathrm{P} 0=200 \mathrm{~g}$ gula pasir, $\mathrm{P} 1=$ jagung manis $50 \mathrm{~g}+150 \mathrm{~g}$ gula pasir, $\mathrm{P} 2=$ jagung manis $100 \mathrm{~g}+100 \mathrm{~g}$ gula pasir, $\mathrm{P} 3=$ jagung manis $150 \mathrm{~g}+50 \mathrm{~g}$ gula pasir, $\mathrm{P} 4=200 \mathrm{~g}$ jagung manis dengan 40 ulangan. Variabel yang diamati yaitu warna, aroma, tekstur, cita rasa. Data yang diperoleh dianalis menggunakan ANOVA, untuk variabel yang berbeda sangat nyata dilanjutkan dengan uji BNJ. Hasil penelitian menunjukkan bahwa substitusi gula pasir dengan ekstrak jagung manis yang berbeda memberikan pengaruh yang nyata $(\mathrm{P}<0,01)$ terhadap aroma, tekstur dan cita rasa, tetapi tidak pada warna. Berdasarkan hasil dan pembahasan bahwa substitusi gula pasir dengan ekstrak jagung manis (Zea mays saccharata) yaitu P1 (150 gram gula pasir dan 50 gram ekstrak jagung manis) memberikan hasil yang baik terhadap sifat organoleptik es krim ekstrak jagung manis
\end{abstract}

Kata kunci : Es krim, Jagung Manis, Gula Pasir

\begin{abstract}
THE EFFECT OF SUBSTITUTION OF SUGAR WITH SWEET CORN (Zea Mays L Sacchara) ON ORGANOLEPTIC PROPERTIES OF ICE CREAM. This study aims to determine the level of preference of panelists on ice cream by substituting sugar with sweet corn extract. This study uses a complete randomized design (CRD) with 5 treatments as follows $\mathrm{P} 0=200 \mathrm{~g}$ sugar, $\mathrm{P} 1=50 \mathrm{~g}$ sweet corn $+150 \mathrm{~g}$ sugar, $\mathrm{P} 2=100 \mathrm{~g}$ sweet corn $+100 \mathrm{~g}$ sugar, $\mathrm{P} 3=150 \mathrm{~g}$ sweet corn $+50 \mathrm{~g}$ sugar, $\mathrm{P} 4=200 \mathrm{~g}$ sweet corn with 40 replications. The observed variables are color, aroma, texture, taste. The data obtained were analyzed using ANOVA, for very significantly different variables followed by the BNJ test. The results showed that the substitution of sugar with different sweet corn extracts had a significant effect $(\mathrm{P}<0.01)$ on the aroma, texture and taste, but not the color. Based on the results and discussion, the substitution of sugar with sweet corn extract (Zea mays saccharata), P1 (150 grams of sugar and 50 grams of sweet corn extract) gives good results on the ice cream organoleptic properties ice cream of sweet corn extracted.
\end{abstract}

Keywords: Ice cream, Sweet Corn, Sugar

\section{PENDAHULUAN}

Air susu merupakan bahan pangan yang sangat dibutuhkan oleh manusia karena mengandung semua komponen bahan yang diperlukan dalam makanan manusia, yang mudah dicerna dan mengandung zat-zat gizi yang lengkap seperti protein, lemak laktosa, air, mineral, vitamin, dan lain-lainnya. Susu mengandung unsur-unsur gizi yang sangat baik bagi pertumbuhan dan kesehatan. 
(Sanam et al., 2014). Guna mempertahankan nilai gizi susu maka salah satu tindakan yang dapat dilakukan adalah dengan mengolah susu menjadi es krim

Es krim merupakan produk olahan susu yang dibuat dengan cara membekukan dan mencampurkan bahan baku secara bersama-sama seperti krim, lemak susu, dan gula, dengan pencampuran bahan yang tepat dan pengolahan yang tepat akan dihasilkan es krim dengan kualitas yang baik. Di Indonesia es krim adalah salah satu produk olahan susu yang sangat populer dan banyak digemari oleh semua kalangan baik anak-anak maupun remaja dan biasanya dikonsumsi sebagai makanan selingan.

Nilai gizi es kim sangat ditentukan oleh bahan baku yang digunakan. Susu sapi, baik susu segar (full cream) maupun lemak susu merupakan bahan utama pada pembuatan es krim. Lemak susu, akan memberikan produk es krim yang kaya akan aroma, dengan tekstur yang lembut, sebagai sumber kalori dan mempunyai kandungan gizi yang lengkap (Fitrahdini et al., 2010).

Dalam pembuatan es krim penambahan gula pasir yang fungsinya untuk meningkatkan cita rasa dapat digantikan dengan gula lain seperti gula pada jagung manis. Gula pasir mengandung suatu molekul yang disebut dengan sukrosa, yaitu suatu molekul gula disakarida yang dalam kondisi asam (misal dalam saluran cerna) akan dipecah menjadi bentuk gula yang lebih sederhana, yaitu glukosa dan fruktosa dalam jumlah yang sama banyaknya. Menurut Prahastuti (2011) gula mengandung gula sederhana yang disebut dengan fruktosa, yaitu jenis gula yang memang sering ditemukan pada buah-buahan dan memiliki rasa yang lebih manis dari gula biasa (1,7 kali lebih manis dari gula biasa). Gula jagung (fruktosa) terbukti memiliki jumlah kalori yang lebih rendah dibandingkan dengan gula biasa (sukrosa). Untuk setiap gram sukrosa mengandung 4 kalori sementara dalam setiap gram fruktosa 3 kalori, oleh sebab itu kadar gula pada jagung manis sangat aman dikonsumsi oleh tubuh manusia Putri et al (2013). Menurut Maherawati dan Sarbino (2018) gula pada endosperm jagung manis adalah sebesar 5-6\% dan kadar pati $10-11 \%$. Sedangkan pada jagung biasa hanya $2-3 \%$ atau setengah dari kadar gula jagung manis.

Dengan kandungan fruktosa dalam Jagung manis juga bisa untuk dikonsumsi orang penyakit diabetes. Menurut Prahastuti (2011), konsumsi fruktosa dalam jumlah sedikit mempunyai efek positif yaitu menurunkan glukosa darah melalui peningkatan uptakeglukosa oleh hepar, stimulasi enzim heksokinase serta peningkatan konsentrasi insulin. Menurut Prabani (2012), jagung mengandung zatzat yang berguna untuk metabolisme tubuh, antara lain gula, kalium, asam jagung, dan minyak lemak. Jagung muda banyak mengandung zat protein, lemak, kalsium, fosfor, besi, belerang, vitamin A, B1, B6, C dan K.

Berdasarkan hasil dan pembahasan bahwa substitusi gula pasir dengan ekstrak jagung manis (Zea mays saccharata) yaitu P1 (150 gram gula pasir dan 50 gram ekstrak jagung manis) memberikan hasil yang baik terhadap sifat organoleptik es krim ekstrak jagung manis

Tujuan penelitian untuk mengetahui tingkat kesukaan panelis terhadap es krim dengan substitusi gula pasir dengan ekstrak jagung manis.

\section{MATERI DAN METODE PENELITIAN}

\section{Materi penelitian}

Bahan yang digunakan dalam pembuatan es krim jagung manis terdiri dari: susu sapi segar, susu skim milk, Wipped Cream, agar-agar, telur, gula pasir, jagung manis. Peralatan yang digunakan adalah terdiri dari timbangan, blender, freezer, gelas ukur, saringan, pisau, mixer, cup ice cream, baskom 
plastic, panci, kompor, dan peralatan untuk uji organoleptik.

Pembuatan ekstrak jagung manis (Zea mays L Saccharata)

Jagung manis dibersihkan dan dicuci bersih, lalu dipisahkan biji jagung dan tongkolnya dengan cara diiris dengan pisau. kemudian siapkan blender dan masukkan biji jagung manis tersebut ke dalam blender dengan ditambahkan air sebanyak $300 \mathrm{~mL}$. Setelah itu disiapkan baskom dan kain kasa untuk penyaringan, kemudian dipanaskan selama 10 menit pada suhu $60^{\circ} \mathrm{C}$ setelah itu dicampurkan ke dalam adonan es krim.

\section{Proses pembuatan es krim jagung manis}

Proses pembuatan es krim jagung manis di mulai dari menyiapkan alat dan bahan yang dibutuhkan, gula pasir dan kuning telur dikocok menggunakan mixer hingga mengental dan berwarna agak putih. Kemudian susu UHT, susu skim milk, dan whippy cream dimixer sampai adonan tercampur dengan baik. Agar-agar dan air $(300 \mathrm{~mL})$ di didihkan selama 5 menit kemudian masukan adonan gula telur dan adonan susu UHT, susu skim milk, whippy cream kemudian di didihkan sampai mendididh, kemudian di pasteurisasi, lalu dan dimixer dan tambahkan konsentrasi jagung manis dan di masukan kedalam freezeer selama 4 jam dengan suhu $-18 \%$. Lalu keluarkan adonan dari freezer kemudian di mixer dan dimasukan kedalam cup cup es krim, kemudian simpan kembali kedalam freezer beku. Penelitian ini dilaksanakan melalui suatu percobaan dengan menggunakan rancangan acak lengkap (RAL) (Steel dan Torrie, 1994) dengan 4 perlakuan dan 40 ulangan (panelis), pengukuran data organoleptik menggunakan uji hedonik (Soekarto dan Hubbies, 1992).

Formulasi bahan-bahan yang sudah digunakan dalam pembuatan es krim jagung manis dapat dilihat pada Tabel 1. Formulasi perlakuan es krim dalam penelitian ini disusun sebagai berikut:
$\mathrm{P} 0=$ Tanpa jagung Manis dengan gula 200 $\mathrm{g}$; $\mathrm{P} 1=$ jagung manis $50 \mathrm{~g}$ dengan gula $150 \mathrm{~g}$; $\mathrm{P} 2=$ jagung manis $100 \mathrm{~g}$ dengan gula $100 \mathrm{~g} ; \mathrm{P} 3=$ jagung manis $150 \mathrm{~g}$ dengan gula $50 \mathrm{~g}$; $\mathrm{P} 4=$ jagung manis 200 $\mathrm{g}$ dengan tanpa gula.

Penelitian ini menggunakan uji organoleptik dengan skala hedonik, di mana panelis yang digunakan adalah panelis tidak terlatih sebanyak 35 orang.

\section{Variabel penelitian} terdiri dari:

Variabel Penelitian yang diukur

Warna (Soekarto dan Hubeis, 1992). Sampel yang diuji ditempatkan di dalam wadah dan setiap sampel diberi kode. Panelis diminta untuk mengamati warna sampel es krim jagung manis kemudian memberikan penilaian dan menuliskannya pada lembar format uji. Kriteria penilaian untuk warna es krim jagung manis adalaha sebagai berikut:

$7=$ Sangat menarik

$6=$ Menarik

$5=$ Agak menarik

$4=$ Netral

$3=$ Agak tidak menarik

$2=$ Tidak menarik

$1=$ Sangat tidak menarik

Aroma (Soekarto dan Hubeis, 1992).

Aroma es krim jagung manis secara organoleptik. Prosedur pengujian untuk aroma yaitu panelis mengambil es krim jagung manis yang telah disiapkan kemufian panelis menghirup aroma dari es krim jagung tersebut, lalu mengisi lembaran format uji sesuai dengan tingkat kesukaan. Kriteria penilaian untuk aroma adalah sebagai berikut :

$7=$ Sangat suka

$6=$ Suka

5= Agak suka

$4=$ Netral

$3=$ Agak tidak suka

$2=$ Tidak suka

$1=$ Sangat tidak suka

Tekstur (Soekarto Dan Hubeis,
1992). Prosedur pengujian untuk


Tabel 1. Formulasi Es Krim Dengan Penambahan Jagung Manis

\begin{tabular}{lccccc}
\hline \multirow{2}{*}{ Bahan } & \multicolumn{5}{c}{ Perlakuan } \\
\cline { 2 - 6 } & P0 & P1 & P2 & P3 & P4 \\
\hline Susu UHT (mL) & 1000 & 1000 & 1000 & 1000 & 1000 \\
Susu skim milk (g) & 200 & 200 & 200 & 200 & 200 \\
Whipped cream (g) & 200 & 200 & 200 & 200 & 200 \\
Agar-agar (g) & 7 & 7 & 7 & 7 & 7 \\
Telur (butir) & 4 & 4 & 4 & 4 & 4 \\
Gula pasir (g) & 200 & 150 & 100 & 50 & 0 \\
Jagung manis (g) & 0 & 50 & 100 & 150 & 200 \\
\hline
\end{tabular}

tekstur yaitu panelis mengambil sampel es krim jagung manis menilai kekasaran dan kehalusan es krim, kemudian mengisi penilaian dalam lembar format uji. Kriteria penilaian tekstur es krim jagung adalah sebagai berikut:

$7=$ Sangat halus

$6=$ Halus

$5=$ Agak halus

$4=$ Netral

3= Agak kasar

$2=$ Kasar

$1=$ Sangat kasar

Cita rasa (Soekarto dan Hubeis, 1992). Cita rasa es krim jagung diuji secara organoleptik. Bahan disiapkan secara acak setiap pindahan sampel berikutnya didahului dengan meminum air putih dan memakan mentimun untuk menetralkan alat indera dalam rongga mulut. Selanjutnya, Panelis mengambil es krim jagung manis yang telah disajikan kemudian es krim jagung manis dimakan atau dicicipi, sesuai dengan tingkat kesukaan dan diisi dalam lembar fomat uji. Kriteria penilaian untuk cita rasa es krim jagung adalah sebagai berikut:

$7=$ Sangat enak

$6=$ Enak

5= Agak enak

$4=$ Netral

$3=$ Agak tidak enak

$2=$ Tidak enak

$1=$ Sangat tidak enak

\section{Prosedur analisis data}

Data yang diperoleh dianalisis menggunakan analisis keragaman (analysis of variance) dengan 4 perlakuan dan ulangan 35 (Steel dan Torrie, 1994), dan jika ada yang berbeda nyata diuji lanjut dengan menggunakan uji BNJ (berbeda nyata jujur).

\section{HASIL DAN PEMBAHASAN}

Uji organoleptik yang dilakukan terhadap suatu bahan pangan merupakan suatu penilaian yang dapat menunjukkan tingkat penerimaann konsumen terhadap produk tersebut. Sifat organoleptik es krim jagung manis yang diamati dalam penilaian ini yakni warna, aroma, tekstur, cita rasa. Hasil pengamatan sifat organoleptik es krim dengan penambahan jagung manis dengan substitusi gula pasir disajikan dalam Tabel 2.

\section{Warna es krim jagung manis}

Rataan nilai warna pada es krim yang menggunakan gula pasir yang di subsitusi dengan ekstrak jagung manis berkisar antara 4,90 (agak menarik) sampai 5,52 (menarik) dengan nilai terendah pada perlakuan P4 (200 gram ekstrak jagung manis tanpa gula pasir) dan yang tertinggi adalah pada perlakuan P0 (200 gram gula pasir tanpa ekstrak jagung manis). Berdasarkan analisis sidik ragam 
Tabel 2. Rataan Sifat Organoleptik Es Krim dengan Penambahan Substitusi Gula Pasir dengan Ekstrak Jagung Manis

\begin{tabular}{llllll}
\hline \multirow{2}{*}{ Variabel } & \multicolumn{5}{c}{ Perlakuan Penambahan Gula Pasir Dengan Ekstrak Jagung Manis } \\
\cline { 2 - 6 } & P0 & P1 & P2 & P3 & P4 \\
\hline Warna & 5,52 & 5,12 & 5,12 & 4,97 & 4,90 \\
Aroma & $5,70^{\mathrm{a}}$ & $5,05 \mathrm{a}$ & $5,07 \mathrm{a}$ & $4,75 \mathrm{~b}$ & $4,55 \mathrm{~b}$ \\
Tekstur & $5,97^{\mathrm{a}}$ & $5,67^{\mathrm{ab}}$ & $5,32^{\mathrm{ab}}$ & $4,32^{\mathrm{b}}$ & $4,12^{\mathrm{b}}$ \\
Cita rasa & $6,45^{\mathrm{a}}$ & $5,70^{\mathrm{ab}}$ & $5,20^{\mathrm{bc}}$ & $4,62^{\mathrm{cd}}$ & $3,72^{\mathrm{d}}$ \\
\hline
\end{tabular}

Ket: Superskrip berbeda pada baris yang sama artinya berbeda sangat nyata $(\mathrm{P}<0,01)$.

menunjukkan bahwa perlakuan substitusi gula pasir dengan ekstrak jagung manis memberikan hasil yang berbeda tidak nyata terhadap warna es krim. Semakin tinggi konsentrasi ekstrak jagung manis maka warna es krim akan semakin kuning, dimana warna kuning pada es krim di dapatkan dari ekstrak jagung manis yang banyak mengandung beta karoten (Putri et al., 2015). Pada penelitian Darma et al. (2013) bahwa tidak terdapat perbedaan nyata tingkat kesukaan panelis terhadap warna es krim. Menurut Moulina (2016) bahwa secara umum warna es krim yang dihasilkan menyerupai warna dari bahan baku susu yang digunakan yaitu cenderung putih kekuning-kuningan.

\section{Aroma es krirm jagung manis}

Rataan nilai aroma pada es krim yang menggunakan gula pasir yang di subsitusi dengan ekstrak jagung manis berkisar antara 4,55 (Agak suka) sampai 5,70 (suka) dengan nilai terendah pada perlakuan P4 (200 gram ekstrak jagung manis tanpa gula pasir ) dan yang tertinggi adalah pada perlakuan P0 (200 gram gula pasir tanpa ekstrak jagung manis). Berdasarkan hasil analisis sidik ragam menunjukkan bahwa perlakuan substitusi gula pasir dengan ekstrak jagung manis memberikan hasil yang berbeda sangat nyata $(\mathrm{P}<0,01)$ terhadap aroma es krim. Hasil uji BNJ menunjukkan bahwa perlakuan P0 tidak berbeda ( $>>0,01)$ dengan $\mathrm{P} 1$ dan $\mathrm{P} 2$, tetapi berbeda sangat nyata $(\mathrm{P}<0,01)$ dengan $\mathrm{P} 3$ dan $\mathrm{P} 4$. $\mathrm{P} 1$ tidak berbeda $(\mathrm{P}>0,01)$ dengan $\mathrm{P} 2$ tetapi berbeda sangat nyata P3 dan P4. P3 tidak berbeda nyata dengan P4. Rata-rata panelis memberikan nilai suka terhadap aroma es krim dengan nilai tertinggi 5,70 pada perlakuan P0 (200 gram gula pasir tanpa ekstrak jagung manis) sedangkan panelis yang memberikan nilai agak suka terhadap aroma es krim dengan nilai terendah $(4,55)$ terdapat pada perlakuan P4 (tanpa perlakuan gula pasir) yaitu es krim beraroma jagung. Semakin tinggi konsentrasi ekstrak jagung manis, maka aroma es krim akan semakin beraroma jagung. Adapun tingkat penerimaan aroma es krim yang diberikan adalah sangat tidak beraroma jagung sampai beraroma jagung. Lanusu et al. (2017), aroma merupakan salah satu komponen yang penting dalam penilaian konsumen terhadap suatu produk. Menurut Suryani (2006) bahwa aroma es krim yang dihasilkan berasal dari aroma khas susu serta bahan tambahan yang digunakan, dan aroma-aroma tersebut dapat mempengaruhi aroma es krim yang dihasilkan. Mahawan (2012), aroma pada es krim yang dihasilkan dipengaruhi oleh bahan subtitusi yang digunakan, aroma pada suatu bahan pangan akan dipengaruhi oleh bahan tambahan yang digunakan seperti penguat cita rasa, tetapi jika penambahan berlebihan akan mengurangi aroma es krim itu sendiri.

\section{Tekstur es krim jagung manis}

Rataan nilai tekstur pada es krim yang menggunakan gula pasir yang di subsitusi dengan ekstrak jagung manis berkisar antara 4,12 (Netral) sampai 5,97 
(Halus) dengan nilai terendah pada perlakuan P4 (200 gram ekstrak jagung manis tanpa gula pasir) dan yang tertinggi adalah pada perlakuan P0 (200 gram gula pasir tanpa ekstrak jagung manis). Berdasarkan hasil analisis sidik ragam menunjukkan bahwa perlakuan substitusi gula pasir dengan ekstrak jagung manis memberikan hasil yang berbeda sangat nyata $(\mathrm{P}<0,01)$ terhadap tekstur es krim. Berdasarkan hasil uji BNJ menunjukkan bahwa perlakuan P0 tidak berbeda nyata $(\mathrm{P}>0,05)$ dengan $\mathrm{P} 1$ dan $\mathrm{P} 2$ tetapi berbeda sangat nyata dengan P3 dan P4. Perlakuan $\mathrm{P} 1$ tidak berbeda nyata $(\mathrm{P}>0,01)$ dengan P2, P3 maupun P4. Sedangkakn perlakuan P3 tidak berbeda nyata $(\mathrm{P}>0,01)$ dengan P4. Tingkat kesukaan panelis terhadap tekstur es krim berkisar dari netral $(4,12)$ sampai halus $(5,97)$, dengan tekstur yang paling disukai adalah tanpa penambahan ekstrak jagung manis. Adanya perbedaan tingkat kesukaan dan penerimaan panelis pada tekstur es krim disebabkan oleh adanya rasio antara gula pasir dengan ekstrak jagung manis. semakin tinggi konsentrasi ekstrak jagung manis, maka tekstur es krim akan semakin kasar sehingga tingkat kesukaan akan semakin berkurang. Menurut Haryanti dan Zueni (2015) bahwa tekstur merupakan salah satu faktor sensoris yang berkaitan dengan tingkat kekerasan dan kelembutan suatu produk. Menurut Muse dan Hartel (2004), faktor yang mempengaruhi kelembutan es krim adalah ukuran kristal es. Semakin besar kristal es krim maka tekstur es krim akan semakin kasar. Kristal yang besar akan terasa licin dan berpasir di mulut Clarke (2008). Menurut Putri (2015), tekstur es krim juga sangat dipengaruhi oleh kadar lemak susu. Semakin tinggi konsentrasi ekstrak jagung manis maka kadar lemak es krim akan semakin rendah. Menurut Santriani et al. (2018) bahwa jagung manis dapat menyebabkan perbedaan karakteristik fisik, terutama berpengaruh pada sifat tekstur es krim karena dalam ekstrak jagung manis mengandung karbohidrat yang sangat tinggi. Sesuai dengan pendapat Dewi et al. (2014), penambahan pati dapat meningkatkan nilai total padatan es krim, karena pati merupakan karbohidrat dimana karbohidrat merupakan salah satu penyusun padatan, selain itu molekul amilopektin pada pati sangat rapat menyebabkan udara tidak bisa masuk, sehingga es krim yang dihasilkan memiliki tingkat kepadatan yang tinggi. Unsur ini dalam pembuatan es krim dapat berfungsi untuk meningkatakan tekstur, menambah cita rasa, meningkatkan dan menstabilkan daya ikat air yang berpengaruh pada kekentalan dan tekstur es krim. Menurut Hasanudin (2011), es krim yang bertekstur kasar mempunyai kekentalan dan resistensi pelelehan yang rendah sehingga mudah meleleh.

\section{Cita rasa es krim jagung manis}

Rataan nilai cita rasa pada es krim yang menggunakan gula pasir yang di subsitusi dengan ekstrak jagung manis berkisar antara 3,72 (Netral) sampai 6,45 (enak) dengan nilai terendah pada perlakuan P4 ( 200 gram ekstrak jagung manis tanpa gula pasir ) dan yang tertinggi adalah pada perlakuan P0 (200 gram gula pasir tanpa ekstrak jagung manis). Berdasarkan hasil analisis sidik ragam menunjukkan bahwa perlakuan substitusi gula pasir dengan ekstrak jagung manis memberikan hasil yang berbeda sangat nyata $(\mathrm{P}<0,01)$ terhadap citarasa es krim. Hasil uji BNJ menunjukkan bahwa perlakuan P0 tidak berbeda $(\mathrm{P}>0,01)$ dengan $\mathrm{P} 1$ tetapi berbeda sangat nyata $(\mathrm{P}<0,01)$ dengan $\mathrm{P} 2, \quad \mathrm{P} 3$ dan $\mathrm{P} 4$. Perlakuan P1 tidak berbeda $(\mathrm{P}>0,01)$ dengan P2 tetapi berbeda sangat nyata $(\mathrm{P}<0,01)$ dengan $\mathrm{P} 3$ dan $\mathrm{P} 4$ sedangkan perlakuan $\mathrm{P} 2$ tidak berbeda $(\mathrm{P}>0,01)$ dengan $\mathrm{P} 3$ tetapi berbeda sangat nyata $(\mathrm{P}>0,01)$ dengan P4. Perlakuaan P3 tidak berbeda $(\mathrm{P}>0,01)$ dengan $\mathrm{P} 4$.

Cita Rasa merupakan sensasi yang terbentuk dari hasil perpaduan komposisi bahan pada suatu produk makanan yang di tangkap oleh indera pengecap (Hartatie, 
2011). Dari hasil penelitian ini rata-rata panelis memberikan nilai kiteria enak terhadap cita rasa es krim terutama pada rasio gula pasir 200 gram tanpa ekstrak jagung manis (P0) yaitu rasa es krim yang manis dan berasa susu. Tingkat penerimaan panelis meunjukkan hasil berbeda sangat nyata. Meskipun ekstrak jagung memiliki rasa manis, akan tetapi konsentrai yang terlalu tinggi dapat menyebabkan kadar air es krim menjadi lebih tinggi sehingga rasa manis pada es krim larut dalam air. Winarno (2002) menyatakan bahwa es krim yang mencair akan terasa sangat manis dibandingkan dengan es krim dalam keadaan beku. Menurut Moulina (2017), rasa manis tersebut dapat bertahan pada es krim diduga karena terdapatnya kandungan gula pasir. Hal ini sesuai dengan laporan Astawan (2008) yang menyatakan bahwa salah satu komponen dari golongan karbohidrat yaitu laktosa yang berfungsi dapat meningkatkan cita rasa, dan mempertahakan palatabilitas es krim. Selain itu cita rasa pada es krim juga sangat dipengaruhi oleh bahan-bahan penyusun es krim yaitu susu, whipped cream, krim bubuk, gula pasir serta bahan tambahan yang digunakan. Menurut Putri (2015) bahwa adanya konsentrasi jagung manis yang semakin tinggi menyebabkan es krim semakin sukar meleleh sehingga es krim dengan konsentrasi jagung yang lebih rendah akan cepat mencair dan lebih terasa manis. Umela (2018) menyatakan bahwa terdapat beberapa faktor yang mempengaruhi kesukaan panelis terhadap rasa, antara lain senyawa kimia, susu, konsentrasi, dan interaksi dengan komponen rasa yang lain.

\section{KESIMPULAN}

Berdasarkan hasil dan pembahasan dapat disimpukan bahwa substitusi gula pasir dengan ekstrak jagung manis (Zea mays saccharata) yaitu P1 (150 gram gula pasir dan 50 gram ekstrak jagung manis) memberikan hasil yang baik terhadap sifat organoleptik es krim ekstrak jagung manis.

\section{DAFTAR PUSTAKA}

Astawan, M. 2008. Sehat dengan hidangan hewani. Penebar Swadaya. Jakarta

Clarke, C. 2008. The Science of Ice Cream. RSC Publishing. Cambridge.

Darma, G. S., D. Puspitasari dan E. Noerhartati. 2013. Pembuatan es krim jagung manis kajian jenis zat penstabil, konsentrasi non dairy cream serta aspek kelayakan finansial. Jurnal REKA Agroindustri 1(1): 45-55.

Dewi, L.K., I. Thohari dan L.E. Radiati. 2014. Pengaruh Penambahan Pati Ubi Cilembu Terhadap Total Padatan, pH, Total Bakteri Asam Laktat dan Organoleptik Es Krim Yoghurt Sinbiotik. Repository Fakultas Peternakan Universitas Brawijaya. Malang.

Fitrahdini, F., U. Sumarwan dan R. Nurmalina. 2010. Analisis Persepsi Konsumen Terhadap Ekuitas Merk Produk Es Krim. Jurnal Ilmu Keluarga \& Konsumen 3(1): 74-81

Hartatie, E. S. 2013. Kajian formulasi (bahan baku, bahan pemantap) dan metode pembuatan terhadap kualitas es krim. Jurnal Gamma, 7(1).

Haryanti, N. dan A. Zueni. 2015. Identifikasi mutu fisik, kimia dan organoleptik es krim daging kulit manggis (Garcinia mangostana L.) dengan variasi susu krim. AGRITEPA: Jurnal Ilmu dan Teknologi Pertanian 2(1).

Hasanuddin, H., K.H. Dewi dan I. Fitri. 2011. Pengaruh proses pembuatan es krim terhadap mutu es krim berbahan baku pisang. Jurnal Agroindustri 1(1): 1-7.

Lanusu, A. D., S. E. Surtijono, L. Ch. M. Karisoh dan E.H.B. Sondakh. 2013. Sifat organoleptik es krim dengan penambahan ubi jalar ungu (Ipomea batatas L). Zootec 37(2): 474-482 
Mahawan, Alim. 2012. Pemanfaatan Umbi Ubi Jalar Ungu Sebagai Bahan Baku Pembuatan Es Krim. Universitas Hasanuddin Makassar.

Maherawati, M. dan S. Sarbino. 2018. Diversifikasi produk olahan jagung manis sebagai upaya peningkatan nilai tambah Bagi petani jagung di daerah wisata Pasir Panjangsingkawang. Jurnal Pengabdi 1(1): 17-25.

Moulina, M. A. 2016. Pemanfaatan jagung (Zea mays L) sebagai bahan pembuatan es krim. AGRITEPA: Jurnal Ilmu dan Teknologi Pertanian 3(2): 32-45.

Muse, M. R. dan R.W. Hartel. 2004. Ice cream structural elements that affect melting rate and hardness. Journal of dairy science $87(1)$ : 1-10.

Prabani, A. 2012. pembuatan es krim jagung manis(zea mays saccharata) dengan proses homogenisasi sebagai salah satu makanan rendah lemak

Prahastuti, S. 2011. Konsumsi fruktosa berlebihan dapat berdampak buruk bagi kesehatan manusia. Maranatha Journal of Medicine and Health 10(2): 151132.

Putri, K. D., M.A. Zaini dan D. Kisworo. 2015. Pengaruh rasio susu full cream dengan jagung manis (Zea mays saccharata) terhadap nilai gizi, sifat fisik dan organoleptik es krim. Pro Food, 1(1), 15-23.

Putri, Y. M., S. Mulyani dan Y.B. Pramono. 2013. Perubahan total gula, serat kasar dan angka iod pada es krim dengan konsentrasi substitusi jagung manism (Zea mays) yang berbeda. Animal Agriculture Journal 2(3): 116-122.

Sanam, A. B., I.B.N. Swacita dan K.K. Agustina. 2014. Ketahanan susu kambing peranakan ettawah postthawing pada penyimpanan lemari es ditinjau dari uji didih dan alkohol. J Veteriner 3(1): 1-8.

Satriani, S., A. Sukainah dan A. Mustarin. 2020. Analisis fisiko-kimia es krim dengan penambahan jagung manis (Zea mays L. Saccharata) dan rumput laut (Eucheuma cottonii). Jurnal Pendidikan Teknologi Pertanian, 4, 105-124.

Umela, S. 2018. Kombinasi terbaik penggunaan susu pasteurisasi dan jagung pulut pada es krim. Journal of Agritech Science 2(1): 58-58.

Winarno, F.G. 2002. Kimia Pangan dan Gizi. PT. Gramedia Pustaka Utama. Jakarta 